\title{
The Effect of Pre Natal Exercise on Pain and Anxiety Third Pregnancy Primigravida in Sukomoro Public Health Center Magetan
}

\author{
Whida Rahmawati ${ }^{1}$, \\ Nurwijayanti², \\ Byba Melda Suhita \\ ${ }^{1}$ Magister of Health Study \\ Program of Institut Ilmu Kesehatan \\ STRADA Indonesia \\ ${ }^{2}$ Lecturer of Institut Ilmu \\ Kesehatan STRADA Indonesia \\ Email: \\ whidarahmawati@gmail.com
}

Received : October 12, 2019

Accepted : February 13, 2020

Published : May 10, 2020

\begin{abstract}
The high complaints and discomfort of pregnant women, especially in primigravida third trimester can result in pregnant women experiencing lower back pain due to changes in posture during pregnancy and the existence of anxiety disorders resulting from psychological changes in pregnant women, especially before labor. One of the efforts made to reduce these symptoms could be by doing a pre natal exercise. One of the benefits pre natal exercise is reduce stress in pregnant women and reduce complication especially musculoskeletal problem. The purpose of this study was to analyze the differences in the influence of lower back pain and anxiety of pregnant women before and after the pre natal exercise. This study used a quasi experimental method with one grub pre and post test design research design. The population of this study was all third trimester primigravida pregnant women who participated in pregnancy exercise at Sukomoro Magetan Health Center. The number of samples is 48 respondents. $43,8 \%$ pregnant women suffer from moderate pain, and $39,6 \%$ pregnants women suffer severe anxiety. Processing and analysis of data using the Wilcoxon test. The results of this study indicate the influence of pre natal exercise on the lowering score of lower back pain by $\mathrm{p}=0.003(<0.005)$, and the decrease in anxiety scores by $p=0.004(0.005)$. The conclusion in this study is the influence of pre natal exercise in reducing lower back pain and anxiety of primigravida third trimester pregnant women.
\end{abstract}

Keywords: Pre natal exercise, low back pain, anxiety

\section{(). (1) ( )}

This is an open-acces article distributed under the terms of the Creative Commons Attribution-ShareAlike 4.0 International License. 


\section{INTRODUCTION}

In pregnancy especially occurs in primigravida pregnant women during third trimester of pregnancy. The musculoskeletal have been the most problem pregnant women experience lower back pain, and subsequent disturbances in the psychological condition of pregnant women like experience anxiety (Anggreani, Rini 2018). Both of these often also affect the mortality rates of pregnant women and infants in Indonesia. In the process of pregnancy pain will arise at the lower waist because the influence of hormones caused disruption in the substance of the base and connective tissue who will decreased elasticity and flexibility ,especially the muscles around the abdomen. Based on a survey conducted on 10 pregnancy women 7 of them had experienced decreasing of pain level after doing pregnancy exercises. This lower back pain was found in $45 \%$ of women and increased by $69 \%$ in the 28th week. The 47 respondents has a majority of gestational age aged 29 weeks 31 peoples part of them has experienced Low Back Pain. In the third trimester of pregnancy with the enlargement of the uterus and the addition of weight and the center of gravity will move towards pregnant woman must adjust the position of the stand. Improper posture will force additional stretching and fatigue in the body, especially in the back. Enlarged of uterus in the front, shifts the center of gravitation back to the lower extremity, during pregnancy there is increased mobility of the sacroiliac joint, sacrocoxigeus, and pubis. This caused by hormonal changes. The mobility of these joints may play a role in changing the posture of the mother and in the end it causes a sense of discomfort, in the lower part of the back, especially at the end of pregnancy (Yosefa, et al, 2015).

In general, women who are pregnant, especially in the third trimester, are afraid of facing labor because of the pain that results in fear and anxiety. Anxiety in pregnant women makes pregnant women easily angry or offended, nervous, unable to focus, hesitant, even want to run away from the reality of life (Gaston, 2011). This can cause mental and physical tension which results in unnatural muscle and joint rigidity. Psychological disorders in pregnant women also increase the risk of complications so prevention is needed to alleviate and prepare the mother to maintaining her pregnancy (Townsend, CM, 1996,). This has a profound effect on maternal and infant mortality in Indonesia.

That problem has influence the level of anxiety facing childbirth are the physical and inner condition of the pregnant woman, personality, life experience, fear and how much support the nearest environment. Fear of labor will have an adverse effect on the mother and fetus. When a person experiences stress or fear, the stimulus will be delivered by receptors throughout the body, the body will automatically secrete catecholamine and adrenaline. Pregnant women who didn't control anxiety and fear before giving birth will release the catecholamine hormone in high concentrations which results in the contraction will feel more painful and painful (Wulandari, PY, 2006).

\section{METHODS}

This study aims to analyze lower back pain of pregnant women before and after pre natal exercise, analyze anxiety in pregnant women before and after pre natal exercise. The type of research used was quasi-experimental using a one group pre and post test design study design, which aimed to determine the benefits of pre natal exercise against low back pain and anxiety in third trimester primigravida pregnant women in the face of labor.

\section{RESULTS}

The research conducted on December 3-22, 2018 at the Sukomoro Magetan Community Health Center was obtained from a total population of pregnant women who performed the examination at the Sukomoro Magetan Health Center, as many as 48 pregnant women. The sample is taken as a whole or total sampling. 


\section{Age Characteristics}

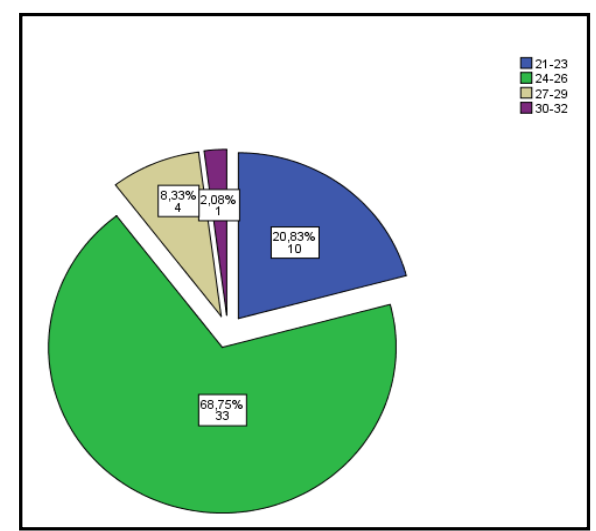

Picture 4.2 Diagram of the Frequency of Age of Primigravida Pregnant Women in Research on December 3-22, 2018

(Source: Primary Data)

Based on the information in figure 4.2 above, it is known that the frequency of the age of primigravida pregnant women who participated in this study was the largest or most at the age of 2426 years with a total of 33 people or $68.75 \%$.

\section{Characteristics of Age of Pregnancy}

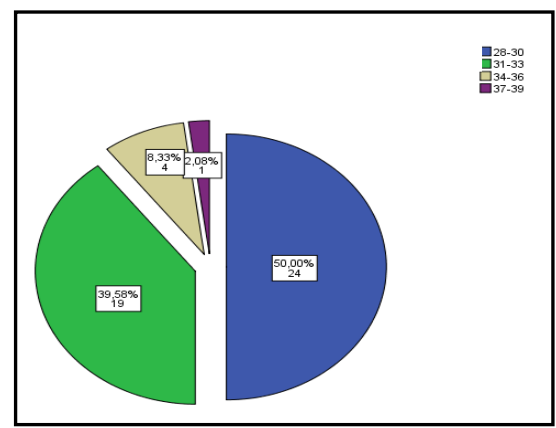

Figure 4.3 Diagram of Frequency of Pregnancy Trimester III Age in Research on December 3-22, 2018

(Source: Primary Data)

Based on information on diagram diagram 4.3, it can be seen that of the total subjects of primigravida pregnant women in the third trimester with the highest gestational age at weeks 28-30 weeks, there were 24 people or $50 \%$.

\section{Characteristics of Education Level}

Figure 4.4 Frequency Chart of Education Levels of Pregnant Women in Research on December 3-22, 2018

(Source: Primary Data) 
Based on Figure 4.4, the diagram of the subject characteristics of the study based on the highest level of education is at the S1 education level of 22 people or $45.83 \%$.

\section{Variable Data of Low Back Pain}

The results of the analysis of the level tables of lower back pain in the third trimester of primigravida pregnant women can be seen in the table below:

Table 4.3 Table of Number of Subjects Viewed From Pain Characteristics (VAS)

\begin{tabular}{|c|c|c|c|c|}
\hline Pain & ¿pre & Presentase & $\Sigma$ post & Presentase \\
\hline Mild (1-3) & 6 & $12,5 \%$ & 17 & $35,4 \%$ \\
\hline Moderat (4-6) & 35 & $72,9 \%$ & 27 & $56,3 \%$ \\
\hline Severe $(7-10)$ & 7 & $14,6 \%$ & 4 & $8,3 \%$ \\
\hline
\end{tabular}

(Source: Research Primer Data December 3-22, 2018)

Based on the table data above, it can be concluded that the highest number of pain before and after treatment is the same as moderate pain. In the previous group it was 35 people or $72.9 \%$ and in the group after 27 people or $56.3 \%$.

Variable Data Anxiety with the HARS Modification scale

Table 4.8 Table of Number of Subjects Viewed From Characteristics of Anxiety (HARS)

\begin{tabular}{|c|c|c|c|c|}
\hline Anxiety & spre & Presentase & $\Sigma$ post & Presentase \\
\hline Mild (15-20) & 0 & 0 & 4 & $8,3 \%$ \\
\hline Moderat (21-27) & 17 & $32,4 \%$ & 14 & $29,2 \%$ \\
\hline Severe $(28-41)$ & 31 & $64,6 \%$ & 30 & $62,5 \%$ \\
\hline
\end{tabular}

Based on the above data table, it can be concluded that the initial subject condition (before the pre natal exercise) when measuring anxiety scale using HARS obtained the highest level of anxiety in the category of severe anxiety as many as 31 people or $64.6 \%$, while the final subject / the post dropped to 30 people. At the level of lightness there is an increase in the number of subjects from 0 to 4 people.

Hypothesis Test I (Pre-Post Difference Test for Low Back Pain)

Table 4.19 Hypothesis I Test Tables Measurement of Lower Back Pain With Wilcoxon

\begin{tabular}{cc}
\hline & Skor vas post-pre \\
\hline $\mathrm{Z}$ & $-2,924$ \\
asymp Sig (2-tailed) & 0,003 \\
\hline
\end{tabular}

(Source: Research Primary Data December 3-22, 2018)

Different pre-post test group I tests used the Wilcoxon test, the results were $p=0.003(p<0.05)$. This means that Ha is accepted and Ho is rejected, meaning there are differences in the level of lower back pain of pregnant women before and after the pre natal exercise is given. 
Test of Hypothesis II (Pre-Post Difference Test Anxiety)

Table 4.20 Hypothesis Test Tables I Measurement of Anxiety With Wilcoxon

\begin{tabular}{cc}
\hline & Skor HARS post-pre \\
\hline $\mathrm{Z}$ & $-2,897$ \\
asymp Sig (2-tailed) & 0,004 \\
\hline
\end{tabular}

(Source: Research Primary Data December 3-22, 2018)

Different pre-post test group I tests used the Wilcoxon test, the results were $p=0.004(p$ $<0.05)$. This means that $\mathrm{Ha}$ is accepted and Ho is rejected, meaning that there are differences in the anxiety level of pregnant women before and after the pre natal exercise is given.

\section{DISCUSSION}

The results of the analysis of data on lower back pain of pregnant women before the pre natal exercise showed that the highest number of pain in the subjects of this study was in the moderate pain category, which was 35 people $(72.9 \%)$. The results of the analysis of lower back pain of pregnant women after the pre natal exercise treatment were the highest number of pain in the subjects of this study were moderate category pain, a total of 27 people $(56.3 \%)$. The results of research conducted at the Sukomoro Magetan Community Health Center on December 3-22, 2018, showed that pre-natal exercises had been conducted on 48 respondents. The number of subjects before the pre natal exercise consisted of 6 people (12.5\%) experiencing mild pain, 35 people $(72.9 \%)$ experiencing moderate pain and 7 people (14.6\%) experiencing severe pain. While the number of subjects after the pre natal exercise consisted of 17 people (35.4\%) experiencing mild pain, 27 people $(56.3 \%)$ experiencing moderate pain and 4 people $(8.3 \%)$ experiencing severe pain. Based on the data above, it can be concluded that there is a decrease in the number of subjects experiencing moderate pain from 35 people to 27 people.

Analysis of differences in the effect of lower back pain on pregnant women before and after the pre natal exercise using the Wilcoxon different test and the results of $p=0.003(<0.005)$ means that there are differences in the level of lower back pain in third trimester pregnant women before and after the pre natal exercise. In this study an analysis of the anxiety level of pregnant women before pre natal exercise was analyzed, the results of these calculations are that the majority of third trimester primigravida pregnant women experienced severe anxiety as many as 31 people (64.6\%) from a total of 48 respondents. Analysis of the anxiety of pregnant women after the pre natal exercise in this study showed that most subjects in the amount of 30 people $(62.5 \%)$ in the third trimester of primigravida pregnant women experienced severe anxiety. The results of the research conducted at the Sukomoro Health Center on December 3-22, 2018, showed that the number of subjects was 48 people. Before pre natal treatment the exercise consisted of 17 people (32.4\%) experiencing moderate anxiety, the remaining 31 people $(64.6 \%)$ experienced severe anxiety. Whereas in the subjects after getting the pre natal exercise the number of subjects who experienced mild anxiety was 4 people $(8.3 \%)$, the subjects who experienced moderate anxiety were 14 people (29.2\%) and the remaining 30 people $(62.5 \%)$ experienced severe anxiety. Based on the data above, it was concluded that there was a decrease in anxiety in the majority of subjects who experienced severe anxiety from 31 people to 30 people.

The Wilxocon test with the results of $p=0.004(<0.05)$ means that Ho is rejected or Ha accepted, ie there are differences in the influence of anxiety before and after the pre natal exercise The results of this study indicate that there is a difference in the effect of pre natal exercise on lower back pain and anxiety in the third trimester of primigravida pregnant women. This pre natal exercise can reduce back pain because in the pregnancy exercise there is a movement that can strengthen the abdominal muscles, when the ligaments around the pelvis tighten and do not provide strong support to the joints, the muscles become the second line of defense to help prevent excessive tension in the pelvic ligaments (Dalyono, 2004). Excessive tension in the pelvis and weakening of the abdominal muscles is what causes back pain, for this reason, exercises such as pregnancy exercise are needed to maintain good abdominal muscle tone. When doing pregnancy exercises the body will produce more endorphins. Endorphins are known as substances that have a working principle such as morphine which serves to provide calm. 
overcome stress during pregnancy and is able to reduce pain such as pain in the back area. In addition, pregnancy exercise movements are useful to tighten the muscles of the buttocks, back, shoulders and abdomen, so that pregnant women who experience back pain after taking pregnancy exercises feel back pain that can be reduced (Carvalho,2015).

In this study there is a decrease in the number of pregnant women who experience severe anxiety, this occurs because pregnant women who have participated in pregnancy exercise feel ready to face childbirth because the benefits of the pre natal exercise itself can facilitate the oxygen supply for the baby, the elasticity of the muscles abdominal wall can be maintained, can overcome tension or pain due to the process of pregnancy, can help in reducing complaints arising from changes in body shape, help facilitate blood circulation, accelerate the process of postpartum recovery (Alibasjah, et al, 2016). The existence of benefits that are known by respondents about pregnancy exercise can affect psychologically so that it can reduce anxiety that arises in third trimester pregnant women before labor (Wahyuni, et al, 2013).

\section{CONCLUSION}

Based on the results of the research and discussion, it can be concluded as follows : Most primigravida third trimester pregnant women before the pre natal exercise experienced moderate low back pain of 35 people $(72.9 \%)$. Most primigravida third trimester pregnant women after pre natal exercise experienced moderate low back pain as many as 27 people (56.3\%). There is a decrease in the number of third trimester primigravida pregnant women who experience low back pain while before and after the pre natal exercise as many as 8 people. Most primigravida third trimester pregnant women before the pre natal treatment experienced severe anxiety as many as 31 people. Most of the third trimester primigravida pregnant women after the pre natal treatment exercise experienced severe anxiety as many as 30 people. There is a decrease in the number of 1-trimester primigravida pregnant women who experience severe anxiety.

\section{SUGGESTION}

\section{For Research Sites}

To improve the quality and quantity of services, a regular and regularly scheduled pregnancy exercise program needs to be implemented so that it can provide maximum effects on the mild complications experienced by pregnant women.

\section{For Pregnant Women}

For pregnant women to get the maximum effect of the pre natal natal exercise, pregnant women are advised to: Do the right check before doing the pre natal exercise, Follow the rules suggested by health workers / pregnant gymnastics instructors in carrying out these activitie, Perform pre natal exercise regularly.

\section{For Further Researchers}

For further researchers to conduct research on more than 1 area of the health center, with the frequency of the implementation of pregnancy exercise improved, and the number of pregnant gymnastic subjects can be increased so that they can obtain more significant results.

\section{REFERENCE}

Alibasjah, et al, 2016. Hubungan Usia Ibu Hamil Trimester III dengan kecemasan menghadapi persalinan pada primigravida di Wilayah Kerja Puskesmas Palimanan Cirebon, Vol. 3 no.1. Diakses melalui http://jurnal.unswagati.ac.id/index.php/tumed/article/vic10/84 . Pada tanggal 17 Januari 2019.

Anggreani, Rini 2018. Pengaruh Senam Hamil Terhadap Penurunan Nyeri Punggung Bawah Ibu Hamil Trimester III di BPM Lismarini. Diakses melalui google http://jurnal.stikesalmaarif.ac.id/index.php/cendekiamedika/article/view/28. Pada tanggal 16 Januari 2019. 
Carvalho, MECC, et all, 2015, Low Back Pain During Pregnancy. Sociede Brasileira de Anestologia.

Dalyono, 2004, Senam Dan Nifas (Tinjauan dari Kebidanan dan Rehabilitasi Medik. RSU dr. Soedono Madiun

Cuningham, Gary, F, 2005, Obstetri William edisi 21, Buku Kedokteran, EGC, Jakarta

Gaston, A, Anita, Cramp, 2011, Exercise During Pregnancy: A Review Of Pattern and Determinants, Journal Of Science and Medicine in Sport, 14 (2011), 299-305

Townsend, CM, 1996, Psychiatric Mental Health Nursing, Conscepts of Care. Fourth Edition. Philadelphia, Davis Company

Wahyuni, Layinatun, Na'imah, 2013. Manfaat Senam Hamil Untuk Meningkatkan Durasi Tidur Ibu Hamil. Diakses melalui google http://journal.unnes.ac.id/nju/index.php/kesmas. Pada tanggal 28$7-2018$

Wulandari, PY, 2006, Efektivitas Senam Hamil sebagai Pelayanan Prenatal dalam Menurunkan Kecemasan Menghadapi Persalinan Pertama. Fakultas Psikologi Universitas Airlangga, INSAN Volume 8, No. 2

Yosefa, F, Misrawati, Yesi Hasneli, 2015, Efektifitas Senam Hamil Terhadap Penurunan Nyeri Punggung Pada Ibu Hamil. 